\title{
KRISIS DUNIA AKIBAT KRISIS KARAKTER DAN KRISIS MANUSIA MODERN
}

\author{
Otong Surasman \\ Pascasarjana Institut PTIQ Jakarta \\ otongmomonsurasman@gmail.com
}

\begin{abstract}
By the middle of 2019 human life is increasingly complex and the progress of technology cannot be avoided, especially the influence of Android. Most people today use Android to fill their lives. Starting from waking up to going back to sleep that is held back is android. Without much thinking that what he does has taken up a large part of his life, which can lead to life's turmoil on the one hand, although there is no denying there is a positive side on the other side. For humans who use their common sense, of course they will be able to filter out what is good and what is bad, so that they will avoid the crisis of character in humans who live in this modern age. Now, to correct the character crisis and the modern human crisis, it is very important to understand and practice the character of the Prophet Abraham in everyday life.
\end{abstract}

Keyword : Character, Modern Human, Prophet Ibrahim

\begin{abstract}
Abstrak
Menjelang pertengahan tahun 2019 kehidupan manusia semakin kompleks dan kemanjuan teknologi tidak bisa dihindarkan, terutama pengaruh android. Hampir sebagian besar manusia saat ini menggunakan android dalam mengisi kehidupannya. Mulai dari bangun tidur sampai menjelang tidur kembali yang digenggam adalah android. Tanpa banyak berpikir bahwa yang dilakukannya telah menyita sebagian besar kehidupannya, yang bisa membawa kepada kegalauan hidup pada satu sisi, walaupun tidak menafikan ada sisi positif pada sisi lainnya. Bagi manusia yang menggunakan akal sehatnya, tentunya akan mampu menyaring mana yang baik dan mana yang buruk, sehingga akan terhindar dari krisis karakter pada manusia yang hidup di zaman modern ini. Nah, untuk memperbaiki krisis karakter dan krisis manusia modern, maka sangat penting memahami dan mempraktekkan karakter Nabi Ibrahim AS dalam kehidupan sehari-hari.
\end{abstract}

Kata Kunci : Karakter, Manusia Modern, Nabi Ibrahim 


\section{A. Pendahuluan}

Penyebutan tahap perkembangan sejarah manusia yang sedang berlangsung sekarang ini sebagai "Zaman Moderen" bukannya tanpa masalah. Masalah itu timbul karena inti dan hakikat zaman sekarang bukanlah kebaruannya (modern berarti baru), seolah-olah sesudah tahap ini tidak ada lagi tahap yang berarti berikutnya. Di samping itu, perkataan "modern" mengisyaratkan suatu penilaian tertentu yang cenderung positif (modern berarti maju dan baik), padahal dari sudut hakikatnya, zaman modern itu sesungguhnya bernilai netral saja.

Dalam referensi lain disebutkan, bahwa kata "Modern" berarti sikap dan cara berpikir serta cara bertindak sesuai dengan tuntunan zaman. Jadi orang yang modern ilmunya tinggi, pengetahuannya banyak, dan wawasannya luas. Sebab, pribadi yang demikianlah yang akan mampu memenuhi tuntutan zaman yang kian hari makin diwarnai oleh teknologi yang semakin canggih ini. Karenanya, ciri utama orang modern ialah berpendidikan dan berbudaya. Kedua hal tersebut akan tercermin dari sikap yang bijak serta prilaku yang sopan dan santun menghadapi siapapun. Pribadinya baik. Pergaulannya senantiasa menggunakan etika. Penampilannya mulai dari pakaian, gerakgerik, serta gayanya selalu sesuai dengan norma yang berlaku. Bukan modern kalau dandanannya berlebihan dan menggunakan aksesoris tidak pada tempatnya, sehingga justru terkesan 'agak berlebihan'. Untuk menjaga citra diri, maka hal yang disebutkan terakhir tadi hendaknya tidak dilakukan oleh SDM unggul.

Informasi di atas yang disampaikan Nurcholis Madjid memberikan gambaran bahwa zaman modern merupakan zaman yang netral saja, mempunyai arti tergantung kepada individu masing-masing. Apakah mau mengambil sikap positif atau sebaliknya? Karena kalau ditelaah secara teliti, zaman modern ini, satu sisi banyak memberikan kemudahan dalam hal duniawi dengan ditemukannya peralatan komunikasi, transfortasi. Namun, pada sisi lain yang menyangkut karakter manusia mengalami kemunduran yang sangat luar biasa, baik dikalangan dewasa terlebih dikalangan remaja.

Sebagai contoh terjadinya sex bebas yang dilakukan remaja maupun dewasa, pada umumnya diakibatkan karena sering melihat video porno yang bisa diakses secara bebas melalui internet. Penyalahgunaan obat-obat terlarang banyak beredar dan sulit untuk diberantas, karena penyebab utamanya adalah karakter manusianya sangat rendah. 
Sementara pendapat yang diutarakan Eman Suherman mengenai definisi modern di atas yang mengatakan bahwa orang yang modern ilmunya tinggi, pengetahuannya banyak, dan wawasannya luas. Sebab, pribadi yang demikianlah yang akan mampu memenuhi tuntutan zaman yang kian hari makin diwarnai oleh teknologi yang semakin canggih ini. Karenanya, ciri utama orang modern ialah berpendidikan dan berbudaya. Merupakan definisi yang sangat idealis, namun pada kenyataannya banyak yang dialami manusia, khususnya bangsa Indonesia saat ini, masih banyak berada di bawah garis kemiskinan dan kebodohan, pendidikannya rendah. Ini berarti bangsa Indonesia pada umumnya, belum mampu beradaptasi dengan zaman modern. Harus ada perombakan secara kontinyu mengenai revolusi mental atau perbaikan karakter manusia Indonesia.

Lihat pula pendapat berikut mengenai ciri-ciri manusia modern, sebagaimana penulis kutip pada "Akhlak Tasawuf dan Karakter Mulia" karya Abuddin Nata adalah sebagai berikut:

1. Bersifat rasional, yakni lebih mengutamakan pendapat akal pikiran, daripada pendapat emosi. Sebelum melakukan pekerjaan selalu dipertimbangkan lebih dahulu untung ruginya, dan pekerjaan tersebut secara logika dipandang menguntungkan.

2. Berpikir untuk masa depan yang lebih jauh, tidak hanya memikirkan masalah yang bersifat sesaat, tetapi selalu dilihat dampak sosialnya secara lebih jauh.

3. Menghargai waktu, yaitu selalu melihat bahwa waktu adalah sesuatu yang sangat berharga dan perlu dimanfaatkan dengan sebaik-baiknya.

4. Bersikap terbuka, yakni mau menerima saran, masukan, baik berupa kritik, gagasan dan perbaikan dari manapun datangnya.

5. Berpikir obyektif, yakni melihat segala sesuatu dari sudut fungsi dan kegunaannya bagi masyarakat.

Dari lima ciri manusia modern di atas, hanya sebagian kecil yang dapat melakukannya dan memiliki sifat tersebut. Karena pada kenyataannya banyak manusia yang tidak bersifat rasional, masih jarang yang berpikir untuk masa depan yang lebih jauh, apalagi yang menghargai waktu, bersikap terbuka dan berpikir obyektif. Oleh sebab itu, agar terwujud lima ciri manusia modern di atas, yang memang sangat positif, maka harus ada perombakan total mengenai karakter manusianya. 
Mulai dari kalangan papan atas (sebut: pemangku jabatan legislatif, eksekutif, yudikatif) berlaku adil, jujur dan memperhatikan kepentingan masyarakat banyak, bukan mementingkan kepentingan pribadi dan golongan saja. Kemudian stabilkan harga kebutuhan pokok masyarakat dan ringankan biaya pendidikan, agar semua kalangan masyarakat bisa menikmati pendidikan setinggi mungkin.

Hal ini dapat dilihat pula pada pendapat berikut: "Permasalahan yang perlu dipecahkan dalam kehidupan modern bukanlah terutama apa yang sering dikemukakan orang sebagai kemunduran kepribadian bangsa karena secara moral menjadi lunak akibat modernisasi, melainkan usaha menanggulangi kehidupan dalam ukuran dan skala yang cepat berkembang dan mengatasi kompleksitas besar pola-pola sosial, ekonomi dan politik. Adalah magnitude (paling penting) dan kompleksitas kehidupan modern itu (yang untuk bisa memahami dan menyertainya seseorang memerlukan antara lain tingkat pendidikan yang tinggi) beserta perubahan yang terlembagakan, sehingga tidak ada hal permanen kecuali perubahan itu sendiri mengakibatkan adanya dislokasi dan disorientasi, mungkin keputusasaan pada banyak orang. Dalam posisi kurang favourable semacam itu, banyak orang mengalami keteringkaran (deprivation), dan keteringkaran ini membuat semakin parah lagi masalah pemerataan dan keadilan sosial."

Informasi lain memberikan penjelasan, bahwa kehadiran ilmu pengetahuan dan teknologi telah melahirkan sejumlah problematika manusia modern, yaitu:

1. Desintegrasi ilmu pengetahuan.

2. Kepribadian yang terpecah.

3. Penyalahgunaan iptek.

4. Pendangkalan iman.

5. Pola hubungan materialistik.

6. Menghalalkan segala cara.

7. Stres dan frustasi.

8. Kehilangan harga diri dan masa depannya.

Elisabeth Lukas, seorang logoteraphis terkenal dengan sangat tepat merumuskan "hasil" dari modernisasi di dunia Barat yang substansinya dua hal, yaitu melepaskan semua belenggu yang menghambat dan meraih kebebasan (freedom) dalam hampir semua bidang kehidupan, antara lain: 


\section{|Otong Surasman}

1. Tradisi orang tua menjodohkan anaknya atas dasar pertimbangan sosial ekonomi (dan agama) telah berhasil dihilangkan. Sebagai gantinya anak-anak diberi kebebasan untuk menentukan sendiri jodohnya atas dasar pertimbangan dan keinginan anak itu sendiri.

2. Kaum wanita berhasil mendobrak kungkungan tradisional sebagai ibu rumah tangga semata-mata, dan sebagai gantinya wanita boleh mengembangkan karir profesioanl kedudukannya sama dengan laki-laki, hingga wanitapun memiliki kebebasan yang dilindungi hukum untuk keluar rumah, sama dengan suaminya.

3. Tradisi kesetiaan kepada keluarga dalam hal hubungan seks berhasil diganti dengan kebebasan seks sepanjang tidak mengganggu orang lain, hingga fungsi hubungan seks sebagai ungkapan cinta kasih, berganti fungsi menjadi tuntutan memperoleh puncak kenikmatan.

4. Tradisi hubungan sakral anak dengan orang tua diganti dengan pola pendidikan menanamkan kemandirian kepada anak, yang memberikan kepada anak di atas usia 18 tahun perlindungan secara hukum untuk terbebas dari kekuasaan tradisioanl keluarga. Hal ini memberikan ruang kepada orang muda untuk masuk kedalam lingkungan nilai serba bolehan. (permissiveness).

5. Aturan-aturan seni tradisioanl yang memiliki simbol-simbol keluhuran nilai, diganti oleh seni modern yang justru "sulit dipahami”.

6. Norma-norma agama sudah diganti oleh norma-norma "rational dan efisien" sehingga agama sudah kehilangan fungsinya sebagai pedoman hidup dan sumber ketenangan.

Oleh sebab itu, peranan pendidikan karakter sangat penting untuk dihadirkan kesemua lapisan pelaku pemerintah dan masyarakat. Pendidikan karakter bukan hanya sebatas teoritis, melainkan dipraktekkan dalam kehidupan nyata. Namun, perlu diingat bahwa untuk mencapai karakter manusia yang sempurna, maka harus mempunyai rujukan yang jelas dan utama. Dalam hal ini, sangat dianjurkan agar mempelajari karakter Nabi Ibrâhîm as, yang sudah jelas mendapatkan bimbingan langsung dari Allah Swt.

Karakter Nabi Ibrahim AS yang diabadikan Al-Qur'an. Ada bebarapa ayat yang menegaskan tentang kedudukan dan kemuliaan Nabi Ibrâhîm as, yang sangat wajar untuk dijadikan contoh atau tauladan bagi manusia, secara khusus manusia yang 
hidup di zaman modern ini. Berikut ini penulis nukil beberapa ayat Al-Qur'ân yang memberikan penegasan mengenai kedudukan, kemuliaan dan perintah agar manusia mengikuti millah Nabi Ibrâhîm as:

1. Anugerah Allah swt kepada Nabi Ibrâhîm as berupa kebaikan di dunia dan di akhirat benar-benar termasuk orang-orang saleh,

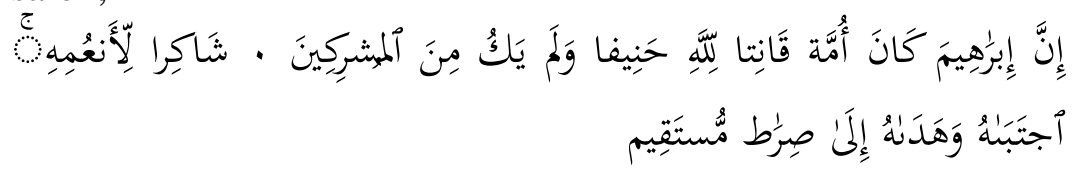

Artinya : Sesungguhnya Ibrahim adalah seorang imam yang dapat dijadikan teladan lagi patuh kepada Allah dan hanif. Dan sekali-kali bukanlah dia termasuk orang-orang yang mempersekutukan (Tuhan), (lagi) yang mensyukuri nikmatnikmat Allah. Allah telah memilihnya dan menunjukinya kepada jalan yang lurus. (Q. S. An-Nahl/16: 120-121).

Pada ayat ini ada lima karakter Nabi Ibrâhîm as, yaitu ummah, qânitalillâh, hanîfâ, tidak pernah musyrik, me nsyukuri segala nikmat. Ummah adalah sosok manusia yang penuh keutamaan dan keteladanan, qânitalillâh patuh sepenuh hati kepada Allah swt, dan hanîfâ selalu cenderung kepada kebenaran lagi konsisten melaksanakannya. Dan Nabi Ibrâhîm as sejak dahulu lagi secara terus menerus-bukanlah dia-termasuk orangorang musyrik serta beliau tidak pernah menyekutukan Allah Swt.

Beliau juga selalu mensyukuri nikmat-nikmat-Nya dengan ucapan dan perbuatannya. Karena kesyukurannya itulah, maka Allah swt telah memilihnya dengan pemilihan yang sempurna sebagai imam, nabi, dan rasul dan membimbingnya ke jalan yang lebar lagi lurus. Dan Kami anugerahkan kepadanya kebaikan, yaitu kenyamanan hidup dan nama baik sehingga selalu diagungkan dan dikenang di dunia. Dan sesungguhnya dia di akhirat nanti benar-benar termasuk kelompok orang-orang yang saleh, yaitu yang mantap kesalehannya sehingga memperoleh pula kebahagiaan ukhrawi.

Kemudian Allah Swt memerintahkan kepada Nabi Muhammad Saw, agar mengikuti millah Nabi Ibrahim AS, sebagaimana dijelaskan dalam firman-Nya:

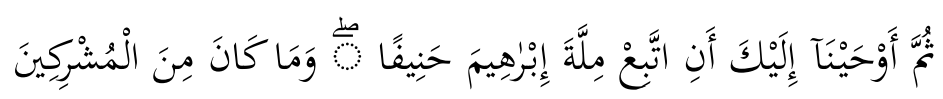


Artinya: "Kemudian Kami wahyukan kepadamu (Muhammad): "Ikutilah agama Ibrâhîm seorang yang hanif" dan bukanlah dia termasuk orang-orang yang mempersekutukan Tuhan."

Pada sûrah An-Nahl/16 ayat 123 ini, dimulai dengan kata kemudian bukan saja untuk mengisyaratkan jauhnya jarak antara Nabi Ibrâhîm as dan Nabi Muhammad saw , tetapi juga untuk mengisyaratkan betapa tinggi dan agung anugerah Allah swt kepada Nabi Ibrâhîm as, yang ajarannya diwahyukan Allah swt agar diikuti oleh Nabi termulia, sekaligus untuk menunjukkan bahwa prinsip-prinsip agama yang disampaikan oleh Nabi Muhammad saw, sama dengan prinsip-prinsip agama Nabi Ibrâhîm as, serta kelanjutan dari ajaran-ajaran beliau.

Setelah diuraikan sifat-sifat mulia Nabi Ibrâhîm as pada ayat sebelumnya, yaitu sûrah An-Nahl/16 ayat 120-122, maka pada ayat 123 sûrah An-Nahl/16 Allah swt memerintahkan kepada Nabi Muhammad saw untuk mengikuti ajaran Nabi Ibrâhîm as, sebagai penguat atas kesempurnaan dan kebenaran tauhid serta jalur lurusnya jalan kehidupan yang ditempuh Nabi Ibrâhîm as dengan firman Allah swt, "Kami wahyukan kepada engkau wahai Rasul agar engkau mengikuti millah/agama Nabi Ibrâhîm as al-hanif/lurus yang menjadi rujukan semua agama, yang memerangi kemusyrikan dan kebatilan menuju ajaran agama tauhid-meng-Esakan Allah Swt, yang mengajak manusia menyempurnakan tauhid, keutamaan akhlak dan amal".

Juga ayat ini, menunjukkan keagungan yang diturunkan Allah swt kepada Nabi Muhammad saw dan sebagai dalil atas kemuliaan, kehormatan dan keagungan nikmat yang diberikan oleh Allah swt kepada Nabi Ibrâhîm as, agar Nabi Muhammad saw mengikuti agamanya Nabi Ibrâhîm as.

Muhammad Mutawali asy-Sya'rawi, Tafsîr asySya'rawi, memberikan penafsiran terhadap ayat dia atas, yaitu ".Al-Haqq Allah swt setelah menyebutkan sebagian sifat-sifat alKhalil Nabi Ibrâhîm as sebagai ummah, qanit lillah, hanif, tidak pernah menyekutukan Allah swt, banyak bersyukur kepada Allah swt, Allah swt memilihnya dan memberikan petunjuk kepada Nabi Ibrâhîm as jalan kebahagian di dunia dan akhirat, maka Allah swt memerintahkan kepada Nabi Muhammad saw, agar mengikuti ajaran Nabi Ibrâhîm as, "Sesungguhnya Kami wahyukan kepada engkau wahai penutup para Rasul, agar engkau mengikuti millah/agama Nabi Ibrâhîm as yang hanif/lurus, yaitu 
syari'at at-Tauhid- syari'at yang menuntut umat manusia agar selalu meng-Esakan Allah swt.

2. Nabi Ibrâhîm as merupakan sebaik-baik manusia,

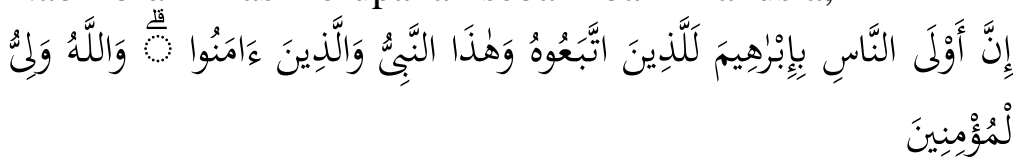

Artinya. Sesungguhnya orang yang paling dekat kepada Ibrâhîm ialah orang-orang yang mengikutinya dan Nabi ini (Muhammad), beserta orang-orang yang beriman (kepada Muhammad), dan Allah adalah pelindung semua orang-orang yang beriman. (Sûrah Ăli Imrân/3: 68).

Wahbah Mushthafâ az-Zuhaili dalam karyanya At-Tafsîr al-Munîr, memberikan uraian terhadap ayat di atas sebagai berikut: "Dalam sûrah Ăli Imrân/3 ayat 68, dijelaskan bahwa Nabi Ibrâhîm as adalah penganut ajaran Islam yang lurus, tidak pernah menyekutukan Allah swt, bukan golongan Yahudi, bukan pula golongan Nasrani, tetapi Nabi Ibrâhîm as merupakan sebaikbaik manusia. Mereka mengikuti tatacara ibadah Nabi Ibrâhîm as, pada masanya maupun pada masa sesudahnya, sebagai muslim yang lurus tidak pernah menyekutukan Allah swt. Demikian pula Nabi Muhammad saw dan orang-orang beriman yang bersamanya, mereka semua ahli tauhid- meng-Esakan Allah swt, dan Allah swt merupakan pelindung dan penolong bagi orangorang mu'min.

Sedangakan M Quraish Shihab dalam karyanya Tafsîr al-Mishbâh, berpendapat: "Ayat ini menetapkan bahwa hanya mereka yang mengikuti Nabi Ibrâhîm as yang wajar dinilai dekat kepada beliau. Memang, mereka tidak sedikit, tetapi secara khusus dan pasti adalah Nabi Muhammad saw. Hal ini bukan saja karena prinsip-prinsip ajaran beliau yang sama, atau sekian banyak syariat agama Nabi Muhammad saw, yang bersumber dari ajaran dan tradisi Bapak nabi-nabi itu, seperti haji, khitan, dan sebagainya, bukan juga hanya pada pelestarian bangunan suci yang dibangunnya, yaitu Ka'bah, tetapi Nabi Muhammad saw , juga sangat dekat dengan beliau dari segi fisik dan kesamaan rupa beliau dengan Nabi Ibrâhîm as, sebagaimana belaiu ungkapkan setelah kembali dari perjalanan mi'raj, di mana Nabi Muhammad saw bertemu dengan para nabi utusan Allah Swt.

3. Kebenaran ajaran Nabi Ibrâhîm as dan perintah mengikutinya,

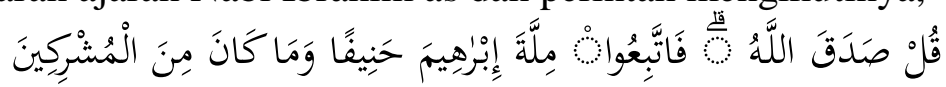


Artinya. Katakanlah: "Benarlah (apa yang difirmankan) Allah". Maka ikutilah agama Ibrâhîm yang lurus, dan bukanlah dia termasuk orang-orang yang musyrik. (Sûrah Ăli Imrân/3: 95).

Pada sûrah Ăli Imrân/3 ayat 95 ini diberikan penjelasan berikut, "Setelah jelas bahwa mereka tidak dapat menunjukkan bukti kebenaran mereka dan setelah terbukti kebohongan mereka, maka Nabi Muhammad saw diperintahkan untuk menyampaikan kepada Ahl al-Kitab bahwa Maha benar Allah dalam segala firman dan ketetapan-Nya, termasuk dalam pengalihan kiblat serta kedudukan Nabi Ibrâhîm as, yang telah membangun kembali pondasi Ka'bah, maka karena itu ikutilah agama Nabi Ibrâhîm as yang lurus, yaitu penyerahan diri kepada Allah swt atas dasar bukti-bukti yang nyata dan pengalaman ruhani yang amat suci, bukan mengikuti adat istiadat yang usang dan tanpa dasar, dan sekali-kali bukanlah Nabi Ibrâhîm as termasuk orangorang yang musyrik, yang mempersekutukan Allah swt dengan sesuatu dan tidak juga mempersekutukan-Nya walau sedikit persekutuan pun.

Katakanlah wahai Nabi Muhammad saw , "Maha benar Allah swt yang telah memberitahukan kepadaku tentang kebenaran ajaran agama Nabi Ibrâhîm as dan aku adalah manusia pertama yang mengenalnya, sesungguhnya Allah swt tidak mengharamkan sesuatu kepada Bani Israil yang dihalalkan sebelum diturunkannya kitab Taurat, demikian juga mengenai perintah Allah swt. Maka ikutilah ajaran agama Nabi Ibrâhîm as, yang mengajak kamu semua untuk mengikutinya. Ajaran Nabi Ibrâhîm as adalah ajaran agama yang mapan, tidak melampaui batas juga tidak berlebihan, dan Nabi Ibrâhîm as tidak pernah menyekutukan Allah swt dengan selain-Nya. Hal ini merupakan dalil yang sangat jelas atas kebenaran kenabian Nabi Muhammad saw. Sesungguhnya Nabi Muhammad saw mengetahui apa yang ada dalam kitab Taurat dengan diturunkannya kitab suci AlQur'ân, dan sesungguhnya Nabi Muhammad saw yang lebih dahulu mengikuti ajaran Nabi Ibrâhîm as, tidak ada perbedaan antara ajaran Nabi Ibrâhîm as dengan ajaran Nabi Muhammad saw. Ajaran Nabi Ibrâhîm as dan Nabi Muhammad saw yang condong/cenderung dari kebatilan kepada kebenaran, dan apa yang dihalalkan pada ajaran Nabi Ibrâhîm as, dihalalkan pula bagi umat Islam.

4. Nabi Ibrâhîm as sebagai kekasih Allah swt, 


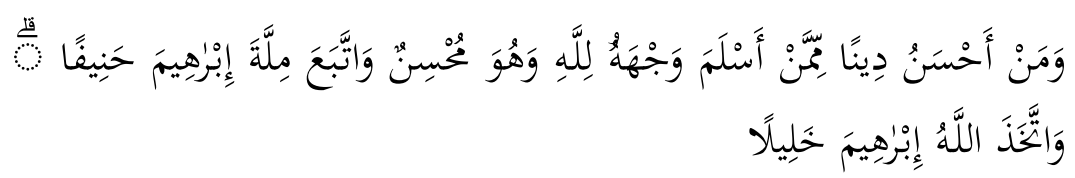

Artinya. Dan siapakah yang lebih baik agamanya dari pada orang yang ikhlas menyerahkan dirinya kepada Allah, sedang diapun mengerjakan kebaikan, dan ia mengikuti agama Ibrahim yang lurus? dan Allah mengambil Ibrahim menjadi kesayangan-Nya. (Sûrah An-Nisâ'/4: 125).

Ibnu Jarir at-Thabar dalam karyanya Jami' al-Bayân 'an Ta'wil Ayi Al-Qur'ân, memberikan penafsiran sebagai berikut: "Sûrah An-Nisâ'/4 ayat 125 ayat ini, merupakan ketetapan Allah swt mengenai ajaran Islam dan keutamaan pemeluknya di atas segala-galanya dengan firman-Nya, "Wahai manusia siapakah yang lebih benar dan mendapatkan petunjuk daripada orangorang yang menyerahkan dirinya kepada Allah swt dengan penuh ketaatan dan membenarkan kenabian Nabi Muhammad Saw, bahwa apa yang dibawanya berasal dari Allah swt, sedang ia muhsin- mengerjakan apa yang diperintahkan Allah swt, mengharamkan apa yang diharamkan-Nya dan mengahalalkan apa yang dihalalkan Allah swt, serta mengikuti ajaran agama Nabi Ibrâhîm as al-Khalîl ar-Rahmân yang selalu menyuruh dan memberi nasehat kepada anak-anaknya dan keturunannya. Beliau adalah seorang hanif - yang selalu istiqamah dalam menempuh jalan kebenaran.

Sedangkan Wahbah Mushthafâ az-Zuhaili dalam karyanya At-Tafsîr al-Wasith, berpendapat: "Tidak ada seseorang yang lebih baik agamanya daripada orang yang menyerahkan hatinya dengan penuh keikhlasan kepada Allah swt, tidak memalingkan wajahnya kepada selain-Nya dalam berdoa dan harapan. Dan menjadikan dirinya merasa tenang karena Allah swt, dan tidak mencari tuhan selain Allah swt, juga tidak ada yang berhak disembah selain-Nya. Sungguh dengan melalui penyerahan hati tunduk terhadap ajaran Islam merupakan cerminan hati, yang mengantarkan hati menjadi ikhlas dan iman menjadi sempurna, terwujud dalam amal yang baik, meninggalkan perbuatan yang jelek, berbudi pekerti yang luhur, dan mengikuti agama Nabi Ibrâhîm as yang lurus, yang jauh dari kemusyrikan dan penyembahan berhala, serta tunduk kepada ajaran agama yang benar yaitu agama Islam. Keutamaan agama Islam atas seluruh agama lainnya adalah terletak pada pijakan pokok kebenaran, pada firman Allah swt sûrah An-Nisâ'/4 ayat 125 di atas, "Mengikhlaskan diri dalam menjalankan agama 
Islam karena Allah swt, menundukkan diri kepada-Nya, serta menghadapkan wajahnya hanya kepada Allah swt dalam beribadah. Dan memandang sebagian ulama bahwa makna muhsin adalah muwahhid-yang beriman pada keesaan Allah swt, maka tidak termasuk ke dalamnya Ahl al-Kitâb karena mereka tidak beriman kepada Nabi Muhammad saw dan tidak mau masuk ke dalam agama Islam yang hanif sebagai Muslim.

Dari empat ayat di atas, begitu sangat jelas mengenai perintah agar mengikuti millah/agama Nabi Ibrâhîm as yang lurus. Pada dua ayat (sûrah An-Nahl/16 ayat 123 dan Ăli Imrân/3 ayat 95) perintah mengikuti ajaran millah/agama Nabi Ibrâhîm as digandengkan dengan pernyataan bahwa Nabi Ibrâhîm as bukanlah termasuk orang-orang yang musyrik, menunjukkan bahwa Nabi Ibrâhîm as benar-benar bersih, suci jauh dari nodanoda syirik walaupun hidup dikalangan para penyembah berhala. Kemudian pada sûrah Ăli Imrân/3 ayat 68 diketahui pula, bahwa Nabi Muhammad saw begitu sangat dekat dengan Nabi Ibrâhîm as, demikian pula orang-orang yang beriman. Dan pada sûrah AnNisâ'/4 ayat 125 ditemukan nilai-nilai utama sebagai prasyarat atau tanda pengikut Nabi Ibrâhîm as, yaitu pertama, aslama wajhahu lillah/ikhlas menyerahkan dirinya kepada Allah; kedua, muhsin (mengerjakan kebaikan), kemudian akhir ayatnya ditutup dengan pernyataan, dan Allah mengambil Nabi Ibrâhîm as menjadi kesayangan-Nya.

5. Ajaran Nabi Ibrâhîm as merupakan ajaran yang benar dan lurus,

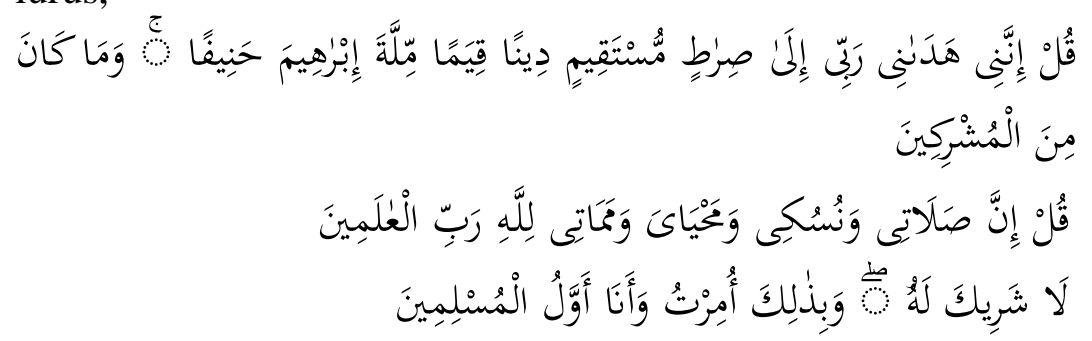

Artinya. Katakanlah: "Sesungguhnya aku telah ditunjuki oleh Tuhanku kepada jalan yang lurus, (yaitu) agama yang benar, agama Ibrâhîm yang lurus, dan Ibrâhîm itu bukanlah termasuk orang-orang musyrik". Katakanlah: Sesungguhnya shalatku, ibadatku, hidupku dan matiku hanyalah untuk Allah, Tuhan semesta alam. Tiada sekutu bagi-Nya; dan demikian itulah yang diperintahkan kepadaku dan aku adalah orang yang pertama-tama menyerahkan diri (kepada Allah)". (Sûrah AlAn'âm/6 ayat 161-163). 
Allah Swt memerintahkan kepada Nabi Muhammad saw, sayyid al-mursalin agar memberitahukan nikmat-nikmat yang Allah swt berikan kepada seluruh umat manusia berupa petunjuk menuju jalan yang lurus, yang tidak ada kebengkokan dan tidak pula melampaui batas, yaitu ajaran agama bapaknya para nabi dan al-Khalîl Nabi Ibrâhîm as, "Katakanlah wahai rasul kepada seluruh umat manusia dan kaummu, 'Sesungguhnya Tuhanku telah memberikan petunjuk kepadaku dan membimbingku kepada kebaikan menuju jalan yang lurus, yang tidak ada kebengkokan di dalamnya, agama yang lurus lagi kokoh, yang mengantarkan kebahagiaan hidup di dunia dan akhirat, penegak kebenaran, ketetapan tauhid atau keimanan, yaitu ajaran agama al-Khalîl Nabi Ibrâhîm as yang jauh dari kemusyrikan dan kesesatan menuju ajaran agama yang haq/agama tauhid. Demikian pendapat Wahbah Mushthafâ az-Zuhaili dalam At-Tafsîr al-Munîr.

Sementara M Quraish Shihab dalam Tafsîr al-Mishbâh memberikan uraian berikut: "Allah s.w.t memerintahkan rasulNya untuk menyampaikan sikap dan pandangan beliau secara jelas dan gamblang yaitu: "Katakanlah kepada semua manusia wahai rasul dan secara jelas dan tegas, sebagaimana dipahami oleh adanya dua huruf "nun" pada kata "innanî", maksudnya adalah sesungguhnya aku telah dibimbing, dan diantar oleh Tuhan Pemelihara-ku masuk ke jalan yang lebar lagi lurus. Jalan yang lurus itu adalah agama yang benar; agama Nabi Ibrâhîm as yang tidak cenderung kepada kebatilan, jauh dari kepercayaan yang sesat tetapi lurus, dan beliau (Nabi Ibrâhîm as) tidak pernah termasuk orang-orang yang musyrik, sebagaimana dugaan sementara kaum musyrik.

Muhammad Nasib ar-Rifa'i, Kemudahan dari Allah Ringkasan Tafsîr Ibnu Katsir, penerjemah: Syihabuddin, berpendapat: "Allah Swt memerintahkan kepada Nabi Muhammad saw untuk memberitahukan karunia hidayah ke jalan yang lurus yang tidak mengandung kebengkokan dan penyimpangan "sebagai agama yang lurus", yaitu teguh dan kokoh, "agama Nabi Ibrâhîm as yang lurus; dan Nabi Ibrâhîm as itu bukanlah termasuk orang-orang yang musyrik."

Firman ini seperti firman Allah swt, "Dan tiada yang membenci agama Nabi Ibrâhîm as, kecuali orang yang memperbodoh dirinya sendiri."Keberadaan Nabi Muhammad saw, menyuruh manusia mengikuti agama Nabi Ibrâhîm as yang hanif, tidaklah memastikan keberadaan Nabi Ibrâhîm as itu lebih sempurna daripada Nabi Muhammad saw. Hal ini karena Nabi 
Muhammad saw, telah menjalankan agama itu dalam suatu kebesaran dan menyempurnakannya secara tuntas dan belum pernah ada orang yang menyempurnakannya sesempurna yang dilakukan Nabi Muhammad saw. Maka Nabi Muhammad saw pun disebut penutup para nabi dan junjungan seluruh anak cucuk Nabi Ădam as, serta pemilik maqam terpuji yang digandrungi oleh para makhluk termasuk oleh al-Khalîl Nabi Ibrâhîm as.

Ajaran yang disampaikan oleh Nabi Muhammad saw dipersamakan dengan miilah Nabi Ibrâhîm as, karena prinsipprinsip ajaran Islam sama dengan prinsip-prinsip ajaran Nabi Ibrâhîm as, yaitu tauhid, kesesuaian dengan fitrah, moderasi, penegakan hak dan keadilan, keramahtamahan, toleransi, lurus, konsisten dalam kebenaran, karena berpijak pada dalil yang kukuh lagi tidak kaku atau bercokol dalam taqlid buta yang terlepas dari cahaya bukti-bukti kebenaran.

Ayat ini dapat dipahami sebagai penjelasan tentang agama Nabi Ibrâhîm as yang disinggung di atas, sekaligus merupakan gambaran tentang sikap Nabi Muhammad saw yang mengajak kaumnya untuk beriman. Ayat 162-163 ini memerintahkan: "Katakanlah wahai Nabi Muhamamad saw, bahwa sesungguhnya shalatku, dan semua ibadahku termasuk korban dan penyembelihan binatang yang kulakukan, dan hidupku bersama segala yang terkait dengannya, baik tempat, waktu, maupun aktivitas dan matiku -berupa iman dan amal saleh yang akan kubawa mati, kesemuanya kulakukan secara ikhlas dan murni hanyalah semata-mata untuk Allah swt, Tuhan Pemelihara semesta alam, tiada sekutu bagi-Nya; dalam zat, sifat dan perbuatan-Nya, antara lain dalam penciptaan alam raya dan kewajaran untuk disembah dan demikian itulah tuntutan yang sangat tinggi kedudukannya lagi luhur, yang diperintahkan kepadaku oleh nalar yang sehat dan juga oleh Allah swt dan aku adalah orang yang pertama-tama dalam kelompok orang-orang muslim, yang paling sempurna kepatuhan dan penyerahan dirinya kepada Allah Swt.

6. Orang yang tidak mengikuti Nabi Ibrâhîm as merupakan orang yang memperbodoh dirinya sendiri,

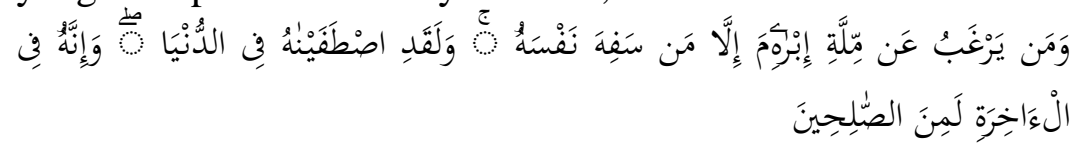


Artinya. Dan tidak ada yang benci kepada agama Ibrâhîm, melainkan orang yang memperbodoh dirinya sendiri, dan sungguh Kami telah memilihnya di dunia dan sesungguhnya dia di akhirat benar-benar termasuk orang-orang yang saleh. (Sûrah Al-Baqarah/2 ayat 130).

Ayat di atas memberikan informasi kepada manusia, yaitu: "Tidak ada yang benci kepada agama Nabi Ibrâhîm as, kecuali orang yang memperbodoh dirinya sendiri, yaitu menzalimi dirinya karena kebodohannya dan kesalahan pengaturannya dengan meninggalkan kebenaran untuk menuju kesesatan dan menyalahi jalan orang yang sudah dipilih untuk menunjukkan dan membimbing sejak dini, sehingga orang itu dijadikan Allah swt sebagai Kekasih. Dan di akhirat, beliau (Nabi Ibrâhîm as) termasuk orang-orang yang saleh dan bahagia. Maka kebodohan apakah yang lebih besar selain meninggalkan jalan, jejak langkah, dan agama Nabi Ibrâhîm as, lalu mengikuti jalan kesesatan dan penyimpangan? Firman Allah swt, "Ketika Tuhan berkata kepadanya, 'Berserah dirilah kamu!' Beliau berkata, 'Aku berserah diri kepada Tuhan semesta alam.' Yaitu ketika Allah swt menyuruhnya memurnikan ketauhidan, ketundukan, dan kepatuhan kepada-Nya, maka Nabi Ibrâhîm as memenuhinya menurut syariat dan ketetapan.

Apakah millah Nabi Ibrâhîm as itu? Millah Nabi Ibrâhîm as adalah ajaran agama yang menunjukkan dan mempertegas bahwa ibadah hanya kepada Allah swt dan tidak ada sekutu bagiNya, serta sangat mencintai untuk melaksanakan kewajiban yang dibebankan Allah swt, karena Nabi Ibrâhîm as merupakan sosok yang sempurna dalam melaksanakan setiap perintah Allah swt, yang diperintahkan kepada beliau. Nabi Ibrâhîm as menerima ujian, beliau laksanakan dengan penuh ketaatan dan kesabaran, termasuk ketika beliau diperintah Allah swt, untuk menyembelih putranya yang satu-satunya, beliau laksanakan tanpa menolaknya dan beliau mewariskan kepada anak cucunya al-manhaj as-salîm (cara menuju jalan keselamatan).

Maka alangkah bodohnya orang yang berpaling dan menolak, serta menghalangi dari ajaran agama Nabi Ibrâhîm as, dan betapa lemahnya akal mereka yang tidak mampu membedakan mana yang bermanfaat dan mana yang membuat bahaya bagi kehidupan mereka. Padahal Allah swt telah memilih Nabi Ibrâhîm as dengan memberikan kebaikan di dunia yang mempunyai kedudukan terhormat dan menjadikannya sebagai imam, serta di akhirat termasuk golongan orang-orang yang 
saleh. Ini merupakan dua nikmat atau anugerah yang Allah swt berikan kepada Nabi Ibrâhîm as sekaligus.

Sesudah Allah swt menjelaskan, mengenai ujian yang diberikan kepada Nabi Ibrâhîm as berupa beberapa perintah, kemudian Nabi Ibrâhîm as menyempurnakan dan melaksanakan perintah tersebut, Allah swt memerintah/menyuruh Nabi Ibrâhîm as untuk membangun Ka'bah dan membersihkannya bagi orangorang yang akan melaksanakan ibadah kepada Allah swt, maka Allah swt menjelaskan tentang millah Nabi Ibrâhîm as, yaitu atTauhid wa Islam al-qalbi Lillah ( ajaran meng-Esakan Allah swt dan ketundukan hati hanya kepada Allah swt semata), seseorang tidak boleh berpaling dari ajaran Nabi Ibrâhîm as dan beliau pun mewasiatkannya kepada anak dan cucunya. Maka tidaklah seseorang membenci dari ajaran agama Nabi Ibrâhîm as, kecuali seseorang yang sangat hina dirinya dan betapa lemah akalnya. Barangsiapa yang meninggalkan kebaikan, kebenaran dan petunjuk sungguh dirinya sangat rendah dan hina. Padahal Allah swt telah memilih Nabi Ibrâhîm as di dunia ini dengan menjadikannya sebagai bapaknya para nabi, dan di akhirat Nabi Ibrâhîm as menjadi saksi bagi mereka yang berbuat kebajikan dan istiqamah, serta menunjukkan kepada manusia agar beramal dengan ajaran agama Nabi Ibrâhîm as.

Tidak ada yang benci kepada agama Nabi Ibrâhîm as, melainkan orang yang memperbodoh dirinya sendiri, yaitu belum/tidak lurus cara berpikirnya, tetapi menduganya lurus, sehingga bertindak keliru. Betapa tidak memperbodoh dirinya sendiri, sedangkan sungguh Kami telah memilihnya di dunia dengan mengangkatnya sebagai nabi dan tauladan. Bukankah melalui pengalaman ruhaninya, beliau menemukan Tuhan Yang Maha Esa dan menyakini-Nya bahwa Dia bukan Tuhan suku atau masa tertentu, tetapi seru sekalian alam?

Bukankah dengan demikian beliau wajar diberi gelar Pengumandang Ketuhanan Yang Maha Esa? Bukankah dengan perantaraan beliau hak-hak asasi manusia terpelihara? Allah swt membatalkan penyembelihan manusia atas nama Tuhan bukan karena manusia terlalu mahal untuk dikorbankan, sebagaimana diduga sementara orang, tetapi karena cinta Allah swt kepada manusia. Ini diajarkan Allah swt melalui keteladanan Nabi Ibrâhîm as. Di dunia ini Nabi Ibrâhîm as mendapatkan kedudukan yang tinggi sebagai nabi dan $A b u$ al-Anbiyâ', sedangkan di akhirat benar-benar termasuk orang-orang yang saleh. 


\section{B. Penutup}

Itulah beberapa uraian penting mengenai karakter dan kedudukan Nabi Ibrahim AS yang diabadikan dalam Al-Qur'an, bilamana dipahami dengan baik dan berusaha engimplementasikan dalam kehidupan, maka masalah krisis dunia modern dapat terselesaikan dengan baik.

\section{Daftar Pustaka}

Al-Alusi, Abî al-Fadhl Shihab ad-Dîn Rûh al-Ma'ânî fî Tafsîr AlQur'ân Al-'Azhîm wa as-Sab' al-Matsânî, Mesir: Dâr al-Hadîs, 2005.

Al-'Azîz, Amîr Abd, At-Tafsîr asy-Syâmil li Al-Qur'ân Al-Karîm, Mesir: Dâr as-Salâm, jilid. 1, cet. 1, 2000.

Al-Banna, Gamal, Tafsîr Al-Qur'ân Al-Karîm Baina al-Qudâmâ wa al-Muhadditsîn, edisi terjemah: Evolusi Tafsîr dari Jaman Klasik hingga Jaman Modern, penerjemah: Novriantoni Kahar, Jakarta: Qisthi Press, cet. 1, 2004.

Al-Baidhawi, Tafsîr al-Baidhawi, Beirut: Dâr al-Kutub al'Ilmiyah, cet. 1, 2003.

Al-Biqai, Burhan ad-Dîn Abi al-Hasan Ibrâhîm bin Umar, Nadhm ad-Durar fî Tanasub al-Ayah wa as-Sur, Beirut: Dâr alKutub al-'Ilmiyah, cet. 3, 2006.

Al-Buruswi, Ismail Haqqi, Tafsîr Rûh al-Bayân, penerjemah: Syihabuddin, Bandung: Dippnegoro, cet. 1, 1996.

Al-Burûsûwiy, Ismâ'îl Haqqiy, Tanwîr al-Adzhân min Tafsîr Rûh al-Bayân, Makkah: Dâr ash-shâbûnî, cet. 1, 1988.

Al-Jamal, Muhammad Abd al-Mun'im, At-Tafsîr al-Farîd Lil Qur'â Al-Majîd, Kairo: Research Publicaation Dept, cet. $1,1952$.

Al-Jazairi, Abu Bakar Jabir, Tafsîr Al-Qur'ân Al-Aisir, penerjemah: M Azhari Hatim dan Abdurrahman Mukti, Jakarta: Darus Sunnah, cet. 2, 2011

Al-Maraghi, Ahmad Mushthafâ, Tafsîr al-Marâghî, Beirut: Dâr al-Fikr, t.th.

Al-Qâsimiy, Muhammad Jamâl ad-Dîn, Tafsîr al-Qâasimiy alMusammâ Mahâsin at-Ta'wîl, Mesir: Dâr al-Hadîs, cet. $1,2003$.

Al-Qunawi, Sadr ad-Din, 'Ijaz al-Bayân fî Tafsîr Um Al-Qur'ân, Beirut: Dâr al-Katab al-Ilmiyah, cet. 1, 2005. 
Al-Qurthubi, Abî Abdillah Muhammad bin Ahmad al-Anshari, Al-Jâmi' li Ahkam Al-Qur'ân, Beirut: Dâr al-Kutub wa al-Ilmiyah, cet. 1, 1988.

Ar-Razi, Fakh al-Din, At-Tafsîr al-Kabîr, ditahqiq oleh Khalîl Muhyiddîn, Beirut: Dâr al-Fikr, 1994.

Ar-Rifai, Muhammad Nashib, Kemudahan dari Allah Ringkasan Tafsîr Ibnu Katsîr, penerjemah: Syihabuddin, jilid. 1,2,3,4, Jakarta: Gema Insani, cet. 3, 2001.

As-Suyûthî, Jalâl ad-Dîn 'Abd ar-Rahmân bin Abî Bakar, AdDurr al-Mantsûr fî̀ at-tafsîr al-Ma'tsûr, Beirut: Dâr alKutub al-'Ilmiyah, cet. 2, 2004.

Asy-Sya'râwî, Muhammad Mutawali, Tafsîr asy-Sya'râwî, jilid. 1, 2, 12, 17, Kairo: Idarah al-Kutub wa al-Maktabat, $1411 \mathrm{H} / 1991 \mathrm{M}$.

Asy-Syaukani, Muhammad bin 'Ăli bin Muhammad, Fath Qadîr al-Jami' baina Fan ar-Riwayah wa ad-Dirayah min 'Ilm at-Tafsîr, Beirut: Dâr al-Fikr, cet. 1, 1983.

Asy-Syanqithi, Adwa'ul Bayâ Tafsir Al-Qur'ân dengan AlQur'ân, Penerjemah: Fathirazi, Jakarta: Pustaka Azzam, cet. 1, 2006.

Ath-Thabari, Abû Ja'far Muhammad bin Jarîr, Jâmi' al-Bayân fî Tafsîr Ayi Al-Qur'ân, jilid. 1, 4, 7, 8, 9, Beirut: Dâr alFikr, 1988.

Ats-Tsalabah, Sayyid Abdurramân, Al-Jawâhir al-Hisan fì Tafsîr Al-Qur'ân, Beirut: Dâr al-Kutub al-'Ilmiyah, cet. 5, 1996.

Asy-Syaukani, Muhammad bin 'Ăli bin Muhammad, Fath alQadîr al-Jâmi' baina Fan ar-Riwayah wa ad-Dirayah min 'Ilm at-Tafsîr, Beirut: Dâr al-Fikr, cet. 1, 1983.

Az-Zuhaili, Wahbah, At-Tafsir al-Munîr, jilid. 1, 2, 5, Beirut: Dâr al-Fikr, cet. II, $1426 \mathrm{H} / 2005 \mathrm{M}$.

, At-Tafsîr al-Wasîth, jilid. 1, 2, 3, Beirut: Dâr al-Fikr al-Mu'hsir, cet. 1, 2001.

Basyîr, Abi al-Hasan Muqâtil bin Sulaimân bin, Tafsîr Muqâtil bin Sulaimân, Beirut: Dâr al-Kutub al-'Ilmiyah, cet. 1, 2003.

Faqih, Kamal dan Tim Ulama, Tafsîr Nûrul Qur'ân, penerjemah: R Hikmat Danaatmaja, Jakarta: Penerbit al-Huda, cet. 1, 2003.

Hamka, Tafsîr al-Azhar, jilid. 1, 3, 5, 6, 9, 11, 12, 17, 23, Jakarta: Panji Masyarakat, TT. 
Hanafi, Muchlis Muhammad dkk, Tafsîr Al-Qur'ân Tematik, AlQur'ân dan Kenegaraan, Jakarta: Lajnah Pentashihan Mushhaf Al-Qur'ân, cet. 1, 2012.

......., Tafsîr Al-Qur'ân Tematik, Kenabian (Nubuwwah) dalam Al-Qur'ân, Jakarta: Lajnah Pentashihan Mushhaf AlQur'an, cet. 1, 2012.

Al-Qur'ân dan Kenegaraan, Jakarta: Lajnah Pentashihan Mushhaf Al-Qur'an, cet. 1, 2012.

Bustaman, Risman, Keteladanan Nabi Ibrâhîm Menurut AlQur'ân, Jakarta: Sekolah Pascasarjana Universitas Islam Negeri Syarif Hidayatullah, 2008.]

Darmiatun, Suryatri, Implementasi Pendidikan Karakter di Sekolah, Yogyakarta: Gama Media, cet. 1, 2013.

Dirks, Jeradl F, Ibrâhîm Sang Sahabat Tuhan, penerjemah: Satrio Wahono, Jakarta: PT Serambi Ilmu Semesta, cet. 2, 2006.

Devries, Manfred Kets, Reflections on Character and Leadership, England: Jossey-Bass, cet. 1, 2009.

Firdaus, Slamet, Konsep Manusia Ideal Dalam Al-Qur'ân (Studi Profil al-Musin dalam Perspektif Tafsîr Ayat-ayat Ihsan), Tangerang: Makmur Abadi Press, cet. 1, 2011.

Fishman, Ethan, William D Perdeson, Nork J Rozell, George Washington; Foundation of Presidentil Leadership and Characater, London: Praeger, cet. 1, 2001.

Hanley, Ryan Patrick, Adam Smith and the Character of Virtue, Cambridge: University Press, cet. 1, 2009.

Husaini, Adian, Pendidikan Islam Membentuk Manusia Berkarakter \& Beradab, Jakarta: Cakrawala Publishing \& Adabi Press, cet. I, 1433 H/2012 M.

Hutcheon, Pat Duffy, Building Character and Culture, London: Praeger, cet. 1, 1999.

Ikhwan, Muahammad, Investagion of Flow and Pressure Characteristic around Pyramidal Building, Karlsruhe: Universitatsverlag, cet. 1, 2005.

Jones, Ffion Mair, The Bard a Very Singular Character Lolo Morgawg Margilania and Privat Culture, Cordiff: University of Wales Press, cet. 1, 2010.

Klann, Gene, Building Character Strengthening The Heart of Good Leadership, San Francisco: John Wiley \& Sons, Inc, cet. 1, 2007. 
Kesuma, Dharma, dkk, Pendidikan Karakter Kajian Teori dan Praktek di Sekolah, Bandung: PT Remaja Rosdakarya, cet. 1, 2011.

Kodir, Abdul, Konsep Manusia Dalam Al-Qur'ân sebagai Dasar Pengembangan Pendidikan, Jakarta: Disertasi UIN Syarif Hidayatullah, 2007.

Kurniawan, Syamsul, Pendidikan Karakter Konsepsi dan Implemnetasinya secara Terpadu di Lingkungan Keluarga, Sekolah, Perguruan Tinggi, dan Masyarakat, Jakarta: Ar-Ruzz Media, cet. 1, 2013.

Lickona, Thomas, Character Matters, New York, Touchstone Rockefeller Center, 2004.

Educating for Character, edisi terjemahan: Mendidik untuk Membentuk Karakter, penerjemah: Juma Abdu Wamaungo, Jakarta: PT Bumi Aksara, cet. 1, 2012.

Lee, Philip Yunglie, 250 Essential Chinese Characters, Singapore: Tuttle Publishing, volume 1, cet. 1, 2009. 250 Essential Chinese Characters, volume 2, cet. 1, 2009

Marif, Ahmad Syafii, Studi tentang Percaturan dalam Konstituante Islam dan Masalah Kenegaraan, Jakarta: LP3ES, cet. 2, 1987.

Majid, Abdul dan Dian Andayani, Pendidikan Karakter Perspektif Islam, Bandung: PT Remaja Rosdakarya, cet. $1,2011$.

Madjid, Nurcholis, Islam Doktrin dan Peradaban, Jakarta: Yayasan Waqaf Paramadina, cet. 4, 2001.

Islam Kemodernan dan Keindonesiaan, Bandung: Mizan, cet. 4, 1991.

Makmun, Abin Syasuddin, Psikologi Kependidikan Perangkat Sistem Pengajaran Modul, Bandung: PT Remaja Rosdakarya, cet. 1, 2002.

Megawangi, Ratna, Pendidikan Karakter Solusi yang Tepat untuk Membangun Bangsa, Bogor: Indonesia Heritage Foundation, cet. 1, 2004.

Mubarok, Achmad, Solusi Krisis Keruhanian Jiwa Manusia Moderen Dalam Al-Qur'ân, Jakarta: Paramadina, cet. 1, 2000.

Mufid, Sofyan Anwar, Islam \& Ekologi Manusia, Bandung: Nuansa, cet. 1, 2010. 
Ekologi Manusia dalam Perspektif Sektor Kehidupan dan Ajaran Islam, Bandung: PT Remaja Rosdakarya, cet. $1,2010$.

Mulyasa, H E, Manajemen Pendidikan Karakter, Jakarta: PT Bumi Aksara, cet. 2, 2012.

Naim, Ngainum, Charakter Building Optimalisasi Peran Pendidikan dalam Pengembangan Ilmu \& Pembentukan Karakter Bangsa, Jogjakarta: Ar-Ruzz Media, cet. I, 2012.

Departemen Pendidikan Nasional, Kamus Besar Bahasa Indonesia Pusat Bahasa, Jakarta: PT Gramedia Pustaka Utama, cet. 4, 2011.

Echols, John M dan Hassan Shadily, An English - Indonesian Dictionary - Kamus Inggris Indonesia, Jakarta: PT Gramedia, cet. 26, 2005.

Farmawi, Abd al-Hayy al, Metode Tafsir Mawdhuiy Suatu Pengantar. Penerjemah: Jamrah, Surya A, Jakarta: Raja Grafindo Persada, 1996, cet. 2.

Gusmian, Islah, Khazanah Tafsîr Indonesia dari Hermeneutika hingga Ideologi, Jakarta: Teraju, cet. I, 2003.

Muslim, Mushthafâ, Mabâhits fì al-Tafsîr al-Maudlu'i, Beirut: Dâr al-Qalam, cet. I, 1998.

Mustaqim, Abdul, Madzahibut Tafsîr Peta Metodologi Penafsiran Al-Qur'ân Periode Klasik hingga Kontemporer, Yogyakarta: Nun Pustaka, cet. 1, 2003.

Basuki, Sulistyo, Metode Penelitian, Jakarta: Penaku, cet.2, 2010. Bungin, Burhan (Ed), Metodologi Penelitian Kualitatif Aktualisasi Metodologis ke Arah Varian Kontemporer, Jakarta: PT RajaGrafindo Persada, cet. 8, 2011.

......., Burhan (Ed), Analisis Data Penelitian Kualitatif Pemahaman Filosofis dan Metodologis ke Arah Penguasaan Model Aplikasi, Jakrta: PT RajaGrafindo Persada, cet. 8, 2011.

Ikbar, Yanuar, Metodologi Penelitian Sosial Kualitatif Panduan Membuat Tugas Akhir/Karya Ilmiah, Bandung: PT Refika Aditama, cet. 1, 2012.

Muhajir, Noeng, Metodologi Penelitian Kualitatif, Yogyakarta: Rake Arasin, 1996.

Moleong, Lexi J, Metodologi Penelitian Kualitatif, Bandung: PT Remaja Rosdakarya, cet. 31, 2013. 